\title{
Recurrent deficit irrigation and fruit harvest affect tree water relations and fruitlet growth in 'Valencia' orange
}

\author{
F.S. Grilo ${ }^{1}$, A. Scalisi ${ }^{1}$, F. Pernice ${ }^{1}$, B. Morandi ${ }^{2}$ and R. Lo Bianco ${ }^{1}$ \\ ${ }^{1}$ Department of Agricultural, Food and Forest Sciences, University of Palermo, Palermo, Italy \\ 2 Department of Agricultural Sciences, University of Bologna, Bologna, Italy
}

\begin{abstract}
Summary
Background - Partial rootzone drying is an irrigation strategy known for increasing water use efficiency without significantly affecting tree water status. 'Valencia' oranges have a very long development period and nearly mature fruit and new fruitlets may be present at the same time on the tree, competing for water and assimilates. Objectives - The present study investigates the effect of recurrent deficit irrigation and fruit harvest on tree water status and fruitlet growth of 'Valencia' orange. Methods - Forty-eight adult trees were exposed to three irrigation treatments for seven years (2007-2013): irrigation with $100 \%$ of ETc (CI), continuous deficit irrigation (DI, $50 \%$ of $\mathrm{CI}$ ) and partial root-zone drying (PRD, $50 \%$ of CI on alternated sides of the root-zone). In spring 2014 , stem water potential $\left(\Psi_{\text {stem }}\right)$ and continuous measurements of sap flow and fruitlet growth were recorded before (May) and after (June) the harvest of mature fruit. Results - No differences in $\Psi_{\text {stem }}$ were found among irrigation treatments, while $\Psi_{\text {stem }}$ was lower in June than in May at midday. In both May and June, sap flow density (not sap flow per tree) was higher in DI than in CI and PRD trees suggesting more efficient water uptake/transport in the former. In May, DI and PRD fruit showed lower daily relative growth rate (RGR) than CI fruit due to a possible shortage of carbon and nutrients. After removing mature fruits, differences among irrigation treatments were canceled. Sap flow was directly related to fruit RGR at low sap flow rates, but inversely related to RGR at high sap flow rates. Conclusions - Our data show that the presence of maturing fruit does not impact the water status of 'Valencia' trees, while it may transiently limit fruitlet growth (by source limitation) in deficit irrigated trees.
\end{abstract}

Keywords

Citrus sinensis, fruit gauges, partial root-zone drying, sap flow, stem water potential, vapor pressure deficit

\section{Introduction}

'Valencia' is a late orange (Citrus sinensis L. Osbeck) cultivar in which fruit develop across a year, ranging from fruitset in late spring of the current year to full ripening in the next spring. This means that for a short time we can find both fruit at stage I and stage III (Iglesias et al., 2007) on the same tree. For this peculiar circumstance, growth rate of current-season 'Valencia' oranges may be influenced by the presence/absence of previous-season, nearly mature fruit. In particular, the presence of older fruit may reduce growth

\section{Significance of this study}

What is already known on this subject?

- Deficit irrigation (DI) can widely improve tree water use efficiency, although tree water use tends to increase with fruit load. However, no information is available on how the long-term adoption of DI strategies, as well as yearly variations in crop load due to harvest, affect the growth of young citrus fruits.

\section{What are the new findings?}

- In 'Valencia' orange, the presence of mature fruit may temporarily limit the growth of young fruits due to resource competition for nutrients and/or carbohydrates. This effect is enhanced by deficit irrigation, although such transient limitation seems not to affect final yield.

What is the expected impact on horticulture?

- The use of deficit irrigation strategies as well as a rational approach to set the correct time of harvest may increase the sustainability and value of 'Valencia' fruit production.

of young fruitlets due to competition for carbohydrates and water. Because of competition for nutrients many fruit abscise during growth (Mehouachi et al., 1995). Initial fruit growth has been shown to be related with phloem and xylem formation (García-Tejero et al., 2012). 'Valencia' orange fruit growth and development follow a double sigmoid curve with three stages (I, II, III) along the season. Stage I is characterized by a slow growth but intense cell division and it lasts approximately two months, from anthesis to June drop (Bain, 1958; Iglesias et al., 2007). During stage I, changes in fruit volume are due to the rind growth. The vascularization of pedicels is completed before stage II of fruit growth. Water back-flow from fruit to xylem has also been observed (Rokach, 1953). Thus, xylem may not just contribute directly to fruit growth but also allow for dissipation of excess water transported by the phloem (Huang et al., 1992). Stage II lasts from four to six months where fruits show a linear growth and are characterized by cell enlargement and differentiation with a consequent high increase in size and fresh weight. Chlorophyll degradation and carotenoid synthesis in the pulp occur gradually during stage II. On the other hand, the peel experiences a rapid color break (green to orange) in the stage III. This stage is also called 'maturation period'. At this moment, a thickening of peel and a reduction of stomatal density strongly decrease water loss by transpiration. Moreover, fruit pulp accumulates sucrose, glucose and fructose in a 2:1:1 ratio (Iglesias et al., 2007). 
In the different stages of fruit growth, fruit daily growth dynamics can change markedly. When water enters the fruit, it can be used for growth, transpiration, or back-flow to other tissues. Rokach (1953) showed that transpiring citrus leaves retrieve water from fruit. In fruit, pulp osmotic potential does not change with water withdrawal from leaves, showing that water is taken up primarily from peel rather than pulp (Rokach, 1953). Consequently, daily fluctuations of fruit diameter are likely to be due to peel water loss rather than pulp shrinkage.

According to Guardiola (1988) and Prado et al. (2007), fruit size is determined by internal and external factors. The internal factors include the genetic characteristics of each fruit and its capacity of acting as a sink. The external factors influencing fruit growth and final size include (a) the availability of plant assimilates, and (b) the competition among plant sink organs (Cary, 1970).

When crop load is high, growth of roots, shoots, and leaves can be reduced. This demonstrates the high priority and sink strength of the fruit within a tree and their capacity to successfully compete with vegetative organs for assimilates (Pavel and DeJong, 1993). Tree crop load can explain up to $50 \%$ of the variability of final fruit size (Guardiola, 1988). High crop load diminishes flower induction and next-season crop load (Prado et al., 2007; Valiente and Albrigo, 2004). Fruit growth dynamics are mainly driven by water inflows via xylem and phloem (Lang, 1990; Morandi et al., 2007a). These fluxes may change over time, depending on the stage of development or resources availability (Garcia-Luis et al., 2002). Relations between fruit diurnal shrinkage and tree water status have been studied in several fruit species, such as avocado (Schroeder and Wieland, 1956), apple (Lang, 1990; Morandi et al., 2011), plum (Intrigliolo and Castel, 2006), peach (Morandi et al., 2007a, 2010a), kiwifruit (Morandi et al., 2012) and oranges (García-Tejero et al., 2012). The continuous monitoring of fruit diameter can provide information of the daily flows of phloem, xylem and transpiration. Many devices for accurate measurement of fruit growth have been developed, such as linear variable displacement transducers (Lang, 1990), strain gauges (Link et al., 1998), linear potentiometer (Morandi et al., 2007b) and even a non-contact optical method (Zeng et al., 2008). Each device may be suitable according to different conditions.

In some areas, such as the Brazilian state of São Paulo, irrigation can increase orchard production up to $50 \%$ (De Souza and Habermann, 2012) compared to rainfed orchards. Regulated deficit irrigation (RDI) is an irrigation practice carried out with a supply of the entire root-zone with an amount of water lower than ET, at specific times during the season. In RDI, the use of water is optimized by supplying it in sensitive tree growth stages. Out of the periods in which plants are more sensitive, irrigation can be either limited or halted if rainfall or soil moisture guarantees a minimum supply of water. RDI is also used in order to control vegetative growth in high-density orchards, and to maximize fruitfulness and fruit quality. Overall, RDI is addressed as a promising water management strategy to optimize water resources (Navarro et al., 2010) and concurrently increase crop productivity (English, 1990). Frequently, if RDI is applied during summer, when fruit are at the initial stage of development, a subsequent rehydration due to winter rainfall may result in no significant changes in final fruit size and juice content (Goldhamer and Salinas, 2000). Another deficit irrigation strategy is PRD, which is designed to maintain half of the root system in a dry or drying state, while the other half is irrigated. The theory behind PRD is based on root-to-shoot chemical signaling in drying soil (Davies et al., 2002; Gowing et al., 1990). Under soil moisture deficit conditions, roots produce chemical signals such as abscisic acid which are transported via xylem to the leaves, causing a partial stomatal closure (Davies et al., 2002; Gowing et al., 1990; Kang and Zhang, 2004; Lo Bianco and Francaviglia, 2012). PRD also involves the exposure of roots to alternate drying and wetting cycles which avoid root death and maintain reduced stomatal conductance without signs of drought stress (Davies et al., 2002; Dos Santos et al., 2003; Kang and Zhang, 2004; Lo Bianco and Francaviglia, 2012; Talluto et al., 2008). In addition, PRD improves yield per unit of applied water with respect to conventional irrigation when high irrigation volumes are provided (Davies et al., 2002; Morison et al., 2008). Nevertheless, the underlying mechanisms of PRD functioning are still a matter of discussion. Field trials with grapes and apple have shown that PRD irrigation may reduce the need of pruning due to an induced low vegetative vigor (Chaves et al., 2007; Talluto et al., 2008). Low vigor increases light penetration to fruit which, in turn, increases peel color and the content of compounds associated with flavor and aroma. Moreover, in apple trees, PRD trees can be supplied with half of the water given to control plants without significant yield reductions (Francaviglia et al., 2013; Talluto et al., 2007, 2008). PRD also improves water use efficiency and irrigation water productivity in various fruit species (Cifre et al., 2005; Kang and Zhang, 2004; Romero et al., 2006; García-Tejero et al., 2011).

Fruit load is known to significantly affect water status in many fruit tree species (Naor, 2006; Intrigliolo and Castel, 2007; Conejero et al., 2010; Silber et al., 2013) but is not considered a factor in evaluating crop water requirements. This study aimed at determining 'Valencia' tree water status and fruitlet growth dynamics in response to harvest of mature fruit and recurrent water deficit. The work specifically focused on the changes in growth dynamics of new fruitlets before (May) and after (June) the harvest of mature fruit as the integrated effect of crop load and fruit development. Furthermore, we wanted to determine if and how water dynamics are affected by several years of deficit irrigation and its influence on fruit growth. It was hypothesized that young fruit growth responds differently to harvest of mature fruit (competition for water and nutrients) based on the plant's ability to extract soil water or store nutrients which, in turn, reflects the irrigation regimes applied in the previous years (adaptive development). This has indirect implications on fruit quality and market price, which can both be improved if fruit can be left longer on trees.

\section{Materials and methods}

\section{Plant material and experimental setup}

The study was carried out on adult orange trees (Citrus sinensis L. Osbeck 'Valencia') grafted on sour orange (Citrus aurantium L.) in an experimental orchard at the Department of Agricultural, Food and Forest Sciences, University of Palermo, Italy (30.06N; $13.21 \mathrm{E}$ and $31 \mathrm{~m}$ a.s.l.). Trees were trained to globe-shaped, raised canopy, topped at 2.5-3 m and spaced at $4 \times 4 \mathrm{~m}$. Starting in summer 2007 and until 2013, three irrigation treatments were imposed to 48 trees in the experimental plot: CI with volumes corresponding to $100 \%$ of crop evapotranspiration $\left(K_{c}=0.65\right.$ from June to September; $K_{c}=$ 0.7 from October to May) applied to the entire root-zone, PRD with $50 \%$ of CI water applied to one alternated side of the root-zone, and DI with $50 \%$ of CI water applied to both 
sides of the root-zone. Average irrigation volumes during the seven seasons were 387, 175, and $186 \mathrm{~mm}$ for CI, PRD and DI, respectively. Irrigation volumes were applied in 20 to 26 events at 2- to 4-day intervals depending on evapotranspiration during the period between June and September. In the field, trees were labeled according to a randomized block design with four blocks and four trees per treatment and block. Further details on irrigation and experimental layouts are reported in Mossad et al. (2017).

Climate data were acquired with two weather stations (Pessl Instruments, Austria) positioned in the experimental plot and equipped with temperature, RH, rain, light, and Watermark soil tension sensors (six in each station). In the years 2007-2013, annual rainfall ranged from 456 to 1,238 mm (average $743 \mathrm{~mm}$ ) and annual reference evapotranspiration $\left(\mathrm{ET}_{0}\right)$ was $1,120 \mathrm{~mm}$, with an average atmospheric water deficit (rain-ET ${ }_{0}$ ) of $-597 \mathrm{~mm}$ in the summer months. Vapor pressure deficit (VPD) was obtained from $\mathrm{RH}(\%)$ and $\mathrm{T}\left({ }^{\circ} \mathrm{C}\right)$ recorded every hour and calculated as $\mathrm{VPD}=\mathrm{VP}_{s}-\mathrm{VP}$, where $\mathrm{VP}$ is the actual vapor pressure and $\mathrm{VP}_{s}$ is the saturated vapor pressure $\left(\mathrm{VP}_{\mathrm{s}}=0.6108 \exp [17.27 \mathrm{~T} /(\mathrm{T}+237.3])\right.$, and $\mathrm{VP}=$ $\mathrm{RH} / 100 \mathrm{Vp}_{\mathrm{s}}$ ).

This work reports data and measurements recorded during spring 2014 before the irrigation season started, while detailed data of tree water relations and growth in response to PRD from the previous years are reported in a recent paper with the same 'Valencia' trees (Mossad et al., 2017). In 2014, mature fruits (end of stage III) from CI, PRD and DI trees were harvested on June 3, when the new season fruitlets (stage I) were already present on the trees. All mature fruit in each tree in trial was harvested, counted and weighed to assess yield and crop load.

\section{Plant water status}

During the seven years of deficit irrigation, soil water potential and leaf relative water content were monitored regularly throughout the irrigation periods. These data are not presented in this work, as they were specifically investigated in another recent study (Mossad et al., 2017). On an average across years (2007-2013), PRD experienced 29\% less soil water deficit and $32 \%$ less leaf water deficit than DI.

In 2014, $\Psi_{\text {stem }}$ was measured throughout the day from pre-dawn until dark (5:00 am; 8:00 am; 12:00 am; 2:00 pm; 5:00 pm; 8:00 pm) on two dates. The first measurement (May 29) was recorded on CI, PRD and DI trees before the harvest of previous-year fruit (full crop load). The second measurement (June 19) was acquired on the same trees after the harvest of mature fruit (only new-season fruitlets present on trees). One mature, healthy leaf from the same branch where fruit gauges were positioned in the west side of each tree was selected, for a total of nine leaves and nine trees (three per irrigation treatment). Each leaf was covered with plastic film and aluminum foil at least 2 hours before measurement, detached from the tree with a razor blade and introduced into a pressure chamber (1505D, PMS Instrument Company, Albany, OR, USA) within 30 seconds according to the methodology described by McCutchan and Shackel (1992), and Naor et al. (1995).

Continuous sap flow measurements were carried out from April 11 to June 22. Sap flow density $\left(\mathrm{mL} \mathrm{cm}^{-2} \mathrm{~min}^{-1}\right)$ was measured with the heat dissipation method developed by Granier (1985). SF-G sensors (Ecomatik, UP-GmbH, Dachau, Germany) were mounted on three trees, one for each treatment. Three probes were placed in each tree, one in the trunk, one in an east-facing branch and one in a west-facing branch.
Direct solar heating was avoided by covering the probes with aluminum foil to minimize temperature fluctuations in the sapwood. The SF-G sensor consists of two identical needles composed by copper-constantan thermocouples and a heating wire. The needles were inserted into the sapwood, one above the other, $15 \mathrm{~cm}$ apart. For the probes installed in the tree trunk, the upper needle was installed at a height of $1.5 \mathrm{~m}$ from the ground and was heated with constant energy supply $(12 \mathrm{~V}, 83 \mathrm{~mA})$. The temperature difference between the two needles was the output signal of the sensor and was used for the calculation of sap flow density as follows (Granier, 1985): $\mathrm{u}=0.714\left[\left(\Delta \mathrm{T}_{\max }-\Delta \mathrm{T}\right) / \Delta \mathrm{T}\right]^{1.231}$, where $\mathrm{u}$ is the sap flow density $\left(\mathrm{mL} \mathrm{cm}{ }^{-2} \mathrm{~min}^{-1}\right), \Delta \mathrm{T}$ is the temperature difference between the two needles and $\Delta \mathrm{T}_{\max }$ is the maximum value of $\Delta \mathrm{T}$ at night. The temperature signals from the probes were recorded at 30-min intervals using a CH6 data logger (GMR Strumenti Sas, Scandicci, Florence, Italy). Trunk/branch circumferences were recorded for calculation of trunk/branch cross-sectional area (TCSA). Conductive sapwood area (CSA) was estimated by digital image analysis according to the method of Coelho et al. (2012). Digital photographs of cut trunks and branches from trees similar to those in trial were acquired and areas of conductive sapwood were estimated from the images and related to TCSA. A linear relationship was obtained (CSA $=0.82 \mathrm{TCSA}-$ 2.32; $\mathrm{R}^{2}=0.996 ; \mathrm{P}<0.001$ ) and used to estimate conductive sapwood area and total sap flow of trees in trial $\left(\mathrm{mL} \mathrm{min}^{-1}\right.$ tree $^{-1}$ ). Trends of daily sap flow and VPD were constructed using averages of seven consecutive days of measurement with uniform weather.

\section{Daily fruit growth}

Daily growth pattern of 'Valencia' orange fruit was estimated with fruit gauges (based on a linear potentiometer) acquiring continuous measurements of fruit diameter (Morandi et al., 2007b). Measurements were made in two sessions of 7 days each, one in late May, the other in mid-June. The first session was recorded on current-year fruit at cell division stage with an average diameter of $11.15 \mathrm{~mm}$ (mature fruit still present on the tree). The second session was acquired on current-year fruit at the late cell division, early cell expansion stage with an average diameter of $27.65 \mathrm{~mm}$ (after complete harvest of mature fruit). Gauges returned values in $\mathrm{mV}$ at 15-min intervals, which were stored in a CR1000 data logger (Campbell Scientific Inc., Logan, UT, USA). Subsequently, data were transferred to a data sheet and converted in $\mu \mathrm{m} \mathrm{min}^{-1}$. The fruit gauges were fixed to 15 fruits at their initial stage of development (five fruits per irrigation treatment).

The transverse diameter of 50 fruits, randomly chosen at similar growth stage, were measured with a digital caliper and weighed. A relationship between fruit diameter and weight was obtained (Weight $=0.003$ Diameter ${ }^{2.46}, R^{2}=0.976$, $\mathrm{P}<0.001$ ), and at each recording time, fruit diameters were converted into fresh weights. Daily AGR $\left(\mathrm{g} \mathrm{min}^{-1}\right)$ and RGR $\left(\mathrm{g} \mathrm{g}^{-1} \mathrm{~min}^{-1}\right)$ were calculated as: AGR $=\left(\mathrm{FW}_{1}-\mathrm{FW}_{0}\right) /\left(\mathrm{t}_{1}-\mathrm{t}_{0}\right)$, and $\mathrm{RGR}=\left(\mathrm{FW}_{1}-\mathrm{FW}_{0}\right) /\left[\left(\mathrm{t}_{1}-\mathrm{t}_{0}\right) \times \mathrm{FW}_{0}\right]$. In the equations, $\mathrm{FW}_{1}$ and $\mathrm{FW}_{0}$ are fruit fresh weights at time $\mathrm{t}_{1}$ and $\mathrm{t}_{0}$, respectively.

\section{Statistical analysis}

SYSTAT procedures (Systat Software Inc., Chicago, IL, USA) were used to carry out analysis of variance on all data, and, when appropriate, means were compared by Tukey's multiple range test. Relationships between VPD and sap flow, and sap flow and fruit RGR were tested using Sigmaplot procedures (Systat Software Inc., Chicago, IL, USA). 


\section{Results and discussion}

\section{Plant water status}

Analysis of $\Psi_{\text {stem }}$ data revealed significant fruit harvest, day time and harvest $\times$ time effects, while no differences were found among irrigation treatments $(P=0.380)$. This was generally expected as the last cycle of deficit irrigation was imposed 11-12 months before $\Psi_{\text {stem }}$ measurements; indeed, soil moisture levels were similar for all irrigation treatments at the time of measurement (data not shown). In general, $\Psi_{\text {stem }}$ decreased in the mid-late morning, reached the most negative values around 2:00 pm, and resumed to pre-dawn values by late evening (Figure 1 ). As expected, predawn values of $\Psi_{\text {stem }}$ were similar in May and June. At 8:00 am (a moment of the day in which light and tree water status are generally favorable), $\Psi_{\text {stem }}$ was higher in June than in May when the presence of mature fruit was acting as a strong sink for water and carbon, possibly determining high leaf photosynthetic and transpiration rates. In June, the slight increase of $\Psi_{\text {stem }}$ at 8.00 am compared to pre-dawn could be explained by the fact that those trees may still be re-hydrating from the night. At $2.00 \mathrm{pm}, \Psi_{\text {stem }}$ was lower in June than in May. This is unexpected since high crop load (May) has been associated to low water potential due to higher competition for water by fruits in other species (Naor et al., 2001, 2008). Several other factors must have contributed to this inverted trend. In part, higher VPD was registered in June than in May (Figure 2), especially in the warmest part of the day, causing lower $\Psi_{\text {stem }}$ as a consequence of higher leaf transpiration. Higher sap flow rates (Figure 2) and stomatal conductance in June $\left(122 \mathrm{mmol} \mathrm{m}^{-2} \mathrm{~s}^{-1}\right)$ than in May $\left(36 \mathrm{mmol} \mathrm{m}^{-2} \mathrm{~s}^{-1}\right)$ during late morning and afternoon also confirm this hypothesis. An additional explanation for the observed differences in water potential may be related to shoot and canopy growth. One of the major growth flushes of 'Valencia' orange trees in Sicily occurs in June, basically after fruit harvest. Also, the dry season generally starts in late June. Hence, a significant increase in total transpiring leaf area, along with certain soil moisture depletion (no irrigation applied), must have occurred from May to June, which in turn, contributed to lowering $\Psi_{\text {stem }}$ in June. In addition, two concurrent mechanisms related to fruit growth stage can further explain the resulting differences in $\Psi_{\text {stem }}$. On one side in June, growing fruits are switching from cell division to cell enlargement, becoming stronger competitors for water at some expenses of leaf hydration. On the other side in May, nearly mature fruit may lose water back to the stems (and act as water reservoirs) when water potential gradients are inverted due to particularly low leaf water potential (i.e., midday) and high leaf transpiration. Similar evidence of backflow from fruit to stem has been documented in orange (Rokach, 1953), apple (Lang, 1990) and kiwifruit (Morandi et al., 2010b).

Daily patterns of VPD showed higher peaks in June (Figure 2b) than in May (Figure 2a). In May, VPD reached a peak of 1.7 $\mathrm{kPa}$ around 1:00 pm, while in June, VPD reached a peak of $2.4 \mathrm{kPa}$ from 10:00 to 12:00 am, earlier than in May. Differences in maximum VPD levels were expected as June is generally warmer than May.

Daily trends of sap flow density were similar in branches (east- and west-oriented) and trunk of trees under each irrigation treatment. Therefore, data from trunks and branches of the same tree were pooled together. Regardless of month or irrigation, sap flows followed the typical bell-shaped trend with nearly absent flow during dark hours and maximum flows during the light hours (Figure 2). Sap flow rates measured in June (Figures $2 \mathrm{~d}$ and f) were slightly higher to those measured in May (Figures 2c and e) reflecting differences in VPD (Figures 2a and b). In May, sap flow peaks for trees of all irrigation treatments were recorded between 12:00 am and 2:00 pm (Figures 2c and e). In June, DI trees exhibited a pronounced peak earlier at 9:00-10:00 am both in terms of sap flow density and sap flow per tree (Figures $2 \mathrm{~d}$ and $\mathrm{f}$ ). Sap flow density was generally higher in DI than in CI and PRD trees, both in May and June (Figures 2c and d); most of those differences were cancelled when sap flow density was converted into total sap flow per tree (Figures 2e and f). This is mainly due to the reduced trunk size of DI trees as a consequence of several years of summer water deficit. The same did not occur in PRD trees which did not experience the same level of water deficit. On the other hand, all trees in trial were regularly pruned to uniform canopy sizes. As a result, DI trees must have adapted to the imposed conditions

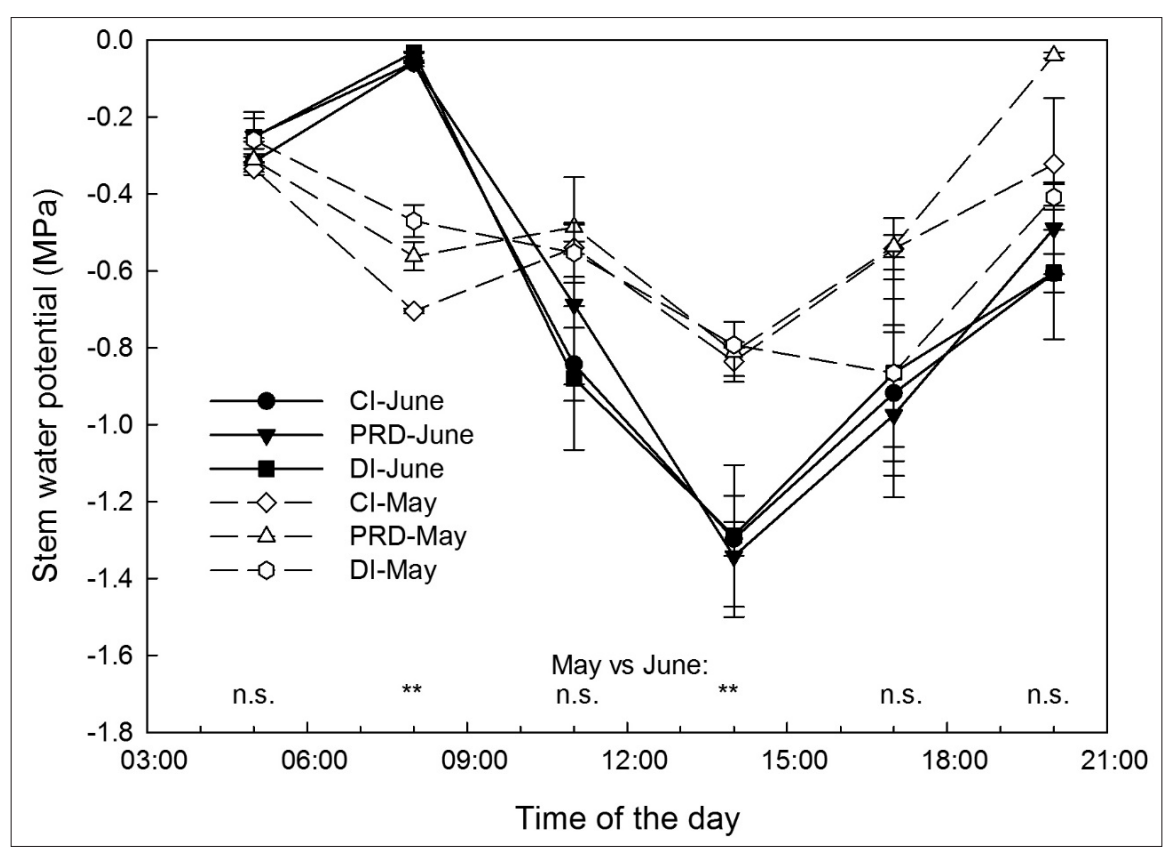

FiguRE 1. Daily trends of stem water potential $\left(\Psi_{\text {stem }}\right)$ in 'Valencia' orange trees under control irrigation $(\mathrm{CI})$, partial root-zone drying (PRD) and continuous deficit irrigation (DI) before (BH, May) and after (AH, June) the harvest of mature fruit. Harvest effect (line on top, $\mathrm{BH}$ vs. $\mathrm{AH}$ ) for a specific day time indicated by ** $(\mathrm{P}<0.01)$ and n.s. (non-significant). Error bars indicate standard errors of means. Predawn potentials measured at 5:00 am. 
(summer water deficit, reduced trunk size but canopies similar to CI and PRD trees) by increasing specific hydraulic conductivity. This is somewhat unexpected as drought generally induces the formation of smaller vessels in stems of various tree species, a mechanism that protects trees from embolism but tends to reduce hydraulic conductivity (Kozlowski and Pallardy, 2002; Fonti and Jansen, 2012). In this study, however, orange trees experienced only transient (summer) and relatively mild drought stress for several consecutive years; they also experienced regular soil moisture conditions for $75 \%$ of the time each year. Under these conditions, it is reasonable that only moderate morphological changes (i.e., vessel size) occurred, whereas physiological adaptations may have induced modifications of ABA-mediated hydraulic conductivity. Indeed, ABA induces expression of aquaporins (Almeida-Rodriguez et al., 2011; Parent et al., 2009), which may act as valves regulating hydraulic conductivity during on- and off-cycles of water deficit.

In June, the early peaks of sap flow in DI trees (Figures $2 \mathrm{~d}$ and $\mathrm{f}$ ) indicate that DI trees were able to satisfy the atmospheric water demand (VPD trends) showing no stomatal control mechanism. Specifically, DI trees maximized their water uptake and transpiration in the early-to-mid morning, taking full advantage of the favourable environmental conditions (high VPD, good light intensity and good soil moisture). This may be due to greater water deficit experienced in the previous years (Mossad et al., 2017) leading to deeper and more efficient (greater hydraulic conductivity) roots compared to CI and PRD trees being able to extract more water during periods of no water deficit. This may be considered a sign of adaptation to recurring water deficit conditions. Indeed, it has been shown that roots grow deeper and increase their uptake efficiency under water deficit (Brunner et al., 2015; Kozlowski and Pallardy, 2002; Hartmann, 2011; Teskey and Hinckley, 1981).

Despite their receiving an equally reduced amount of irrigation water during summer, on an average across the irrigation seasons PRD trees experienced 32\% less water deficit than DI trees (Mossad et al., 2017); as a consequence, they did not adjust to the reduced irrigation regime like DI trees. This is consistent with the results of a number of PRD studies on several fruit species which show clear differences between PRD and continuous water deficit. Those differences are mainly due to the ability of roots under alternating

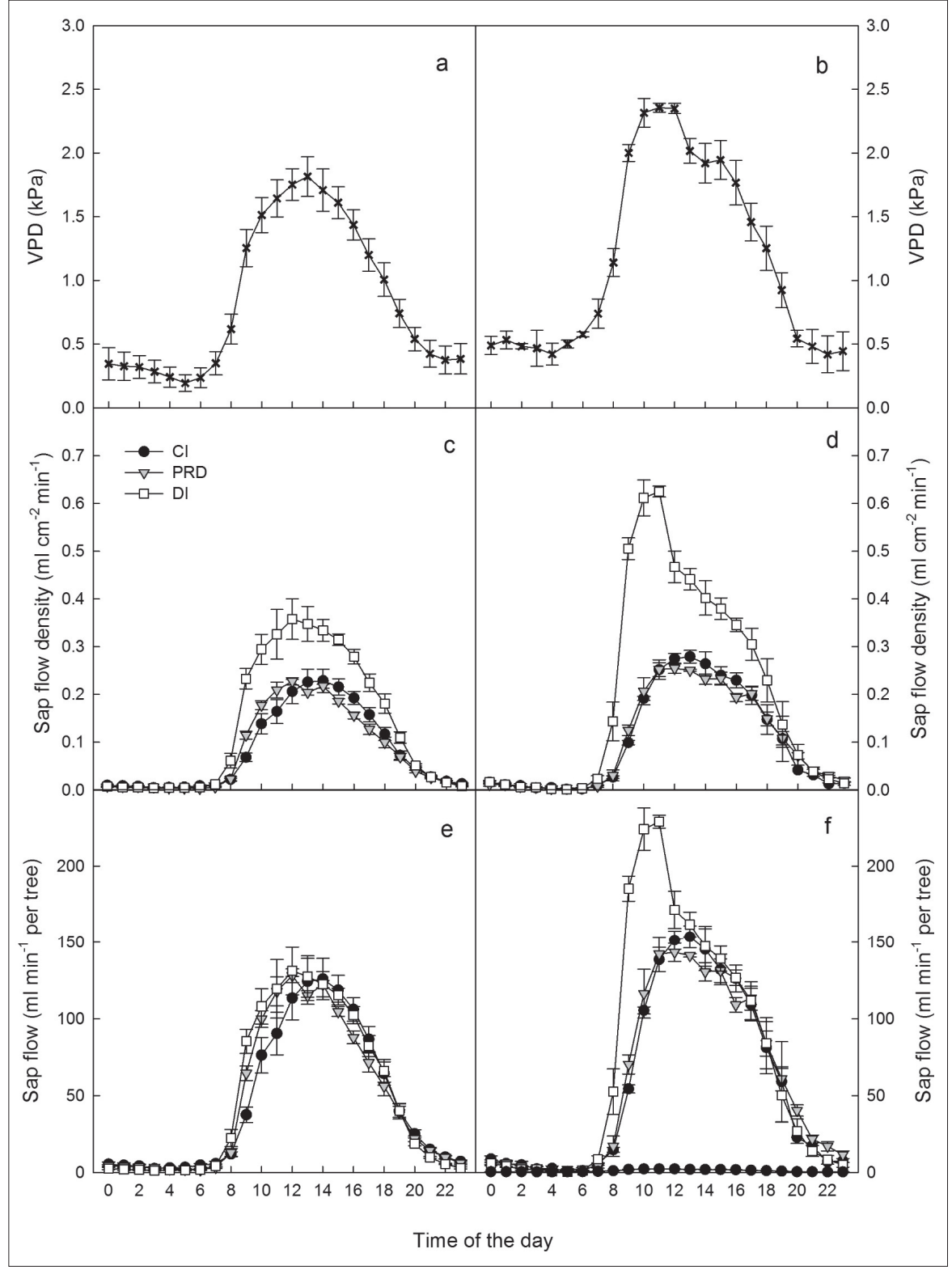

FiguRE 2. Daily trends of vapor pressure deficit (VPD, A and B), sap flow density (C and D) and sap flow per tree (E and F) in 'Valencia' orange trees under control irrigation (CI), partial root-zone drying (PRD) and continuous deficit irrigation (DI), before (A, C and $\mathrm{E}$ ) and after (B, D and F) the harvest of mature fruit. Data are means of seven consecutive days of measurement and three sensors (sap flow only); error bars indicate standard errors of means. 
drying and wetting cycles to produce and translocate ABA to shoots, inducing partial stomatal closure and avoiding significant leaf dehydration or major growth reductions (Davies et al., 2002; Dos Santos et al., 2003; Kang and Zhang, 2004; Lo Bianco and Francaviglia, 2012; Mossad et al., 2017; Talluto et al., 2008). As a result, trees under PRD do not experience as much water deficit as DI trees (and do not show the same symptoms). This is also shown in the present study on a long-term perspective as PRD trees showed no adaptation to water deficit and in many cases, responded in a fashion closer to CI than DI trees.

\section{Fruit production}

At fruit harvest on June 3, 2014, no differences in term of crop load, yield per tree and fruit weight were observed among irrigation treatments imposed in summer 2013 (Table 1). The present results confirm what was found in previous PRD works with citrus (Consoli et al., 2017; Goldhamer and Salinas, 2000; Kusakabe et al., 2016; Mossad et al., 2017; Perez-Perez et al., 2012), as well as in a number of PRD studies on late-maturing fruit species and cultivars including apple (Lo Bianco, 2013). It is argued that the lack of yield reductions in response to deficit irrigation of late-maturing fruits may be due to the recovery of fruit growth after fall, winter and spring rainfalls. In contrast, studies conducted on Navel oranges found that deficit irrigation decreases crop load (Faber and Lovatt, 2014; Treeby et al., 2007). Again, this can be ascribed to the different duration of the fruit development period between these two varieties, 13 months for 'Valencia' and nine months (October-June in the Southern hemisphere) for 'Bellamy Navel' oranges. Despite the lack of statistical differences, it is worth to notice however that CI

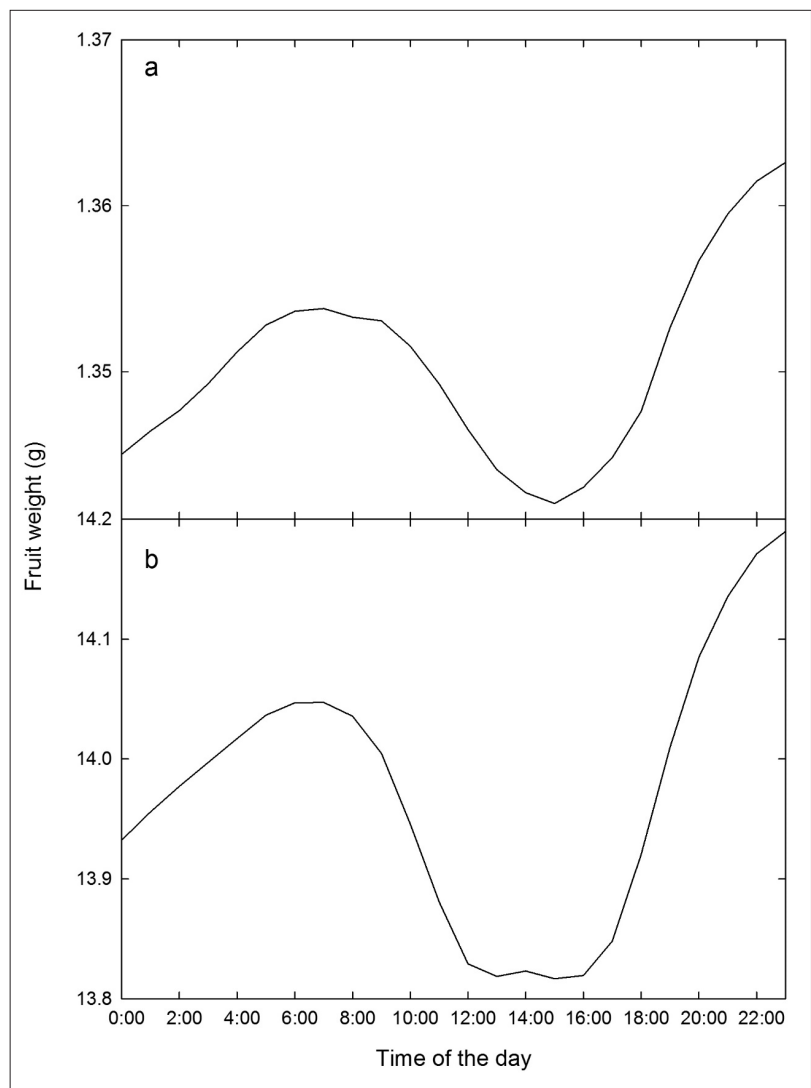

FIGURE 3. Average daily weight fluctuation of 'Valencia' orange fruitlets before (A) and after (B) the harvest of mature fruit.
TABLE 1. Crop load, yield per tree and average fruit weight of 'Valencia' trees under conventional irrigation (CI), partial root-zone drying (PRD) and deficit irrigation (DI). Data from the 2014 fruit harvest. Means \pm standard errors $(n=16)$.

\begin{tabular}{lccc}
\hline Treatment & $\begin{array}{c}\text { Crop load } \\
(n)\end{array}$ & $\begin{array}{c}\text { Yield per tree } \\
(\mathrm{kg})\end{array}$ & $\begin{array}{c}\text { Fruit weight } \\
(\mathrm{g})\end{array}$ \\
\hline $\mathrm{Cl}$ & $149 \pm 36.6$ & $27.1 \pm 5.99$ & $189 \pm 8.39$ \\
$\mathrm{PRD}$ & $111 \pm 28.3$ & $19.3 \pm 4.17$ & $192 \pm 12.0$ \\
$\mathrm{DI}$ & $137 \pm 33.5$ & $23.8 \pm 5.47$ & $182 \pm 6.28$ \\
\hline P value & 0.552 & 0.506 & 0.722 \\
\hline
\end{tabular}

tended to produce a greater number of fruit per tree compared to PRD, whereas PRD tended to produce larger fruit than CI. This crop load to fruit weight compensation mechanism in response to PRD has also been observed in apple, especially with late-ripening cultivars (Lo Bianco, 2013; Talluto et al., 2008).

\section{Daily fruit growth}

In both May and June, the typical pattern of daily fruit weight fluctuations was observed in new season fruitlets (stage I) (Figure 3). Indeed, fruit gained weight from late afternoon to early morning and lost weight in the remaining part of the day, from mid-morning to early afternoon, when VPD increased and $\Psi_{\text {stem }}$ decreased. Fruit shrank reaching a minimum weight from 12:00 am to 4:00 pm, whereas they reached their maximum weight at 7:00 am. This pattern is similar to what has been recorded for many temperate fruits such as apple (Lang et al., 1990), pear (Morandi et al., 2014), peach (Morandi et al., 2007a) and kiwifruit (Morandi et al., 2010b), where morning hours are characterized by low xylem and phloem flows, due to relatively low stem-to-fruit water potential gradients. During the afternoon, fruit water potential tends to decrease due to water losses by epidermis transpiration and/or xylem backflow from fruit to stem occurring during the previous hours, while $\Psi_{\text {stem }}$ tends to increase thanks to reduced leaf stomatal conductance (Morandi et al., 2010b, 2014). As a consequence, in the late-afternoon the fruit capacity to attract water through xylem and phloem flow increases, as well as fruit AGR.

TABLE 2. Daily absolute growth rate (AGR, $g \mathrm{~min}^{-1}$ ) and relative growth rate (RGR, $\left.\mathrm{g} \mathrm{g}^{-1} \mathrm{~min}^{-1}\right)$ of young fruit in 'Valencia' orange trees under conventional irrigation (CI), partial root-zone drying (PRD) and continuous deficit irrigation (DI). Measurements were taken before (May) and after (June) harvest of mature fruit on five fruits per irrigation treatment and for seven consecutive days. Different letters indicate significant differences among levels of the irrigation factor in May or June (Tukey's test, $\mathrm{P} \leq 0.05$ ).

\begin{tabular}{lccc}
\hline Month & Irrigation & $\begin{array}{c}\mathrm{AGR} \\
\left(\mathrm{mg} \mathrm{min}^{-1}\right)\end{array}$ & $\begin{array}{c}\text { RGR } \\
\left(\mathrm{mg} \mathrm{g}^{-1} \mathrm{~min}^{-1}\right)\end{array}$ \\
\hline May & $\mathrm{Cl}$ & $0.005 \mathrm{a}$ & $0.003 \mathrm{a}$ \\
& $\mathrm{PRD}$ & $0.002 \mathrm{~b}$ & $0.001 \mathrm{~b}$ \\
& $\mathrm{DI}$ & $0.002 \mathrm{~b}$ & $0.001 \mathrm{~b}$ \\
\hline June & $\mathrm{Cl}$ & 0.019 & 0.002 \\
& $\mathrm{PRD}$ & 0.021 & 0.002 \\
& $\mathrm{DI}$ & 0.019 & 0.002 \\
\hline \multicolumn{2}{l}{ Month $\times$ Irrigation } & $\mathrm{P}<0.001$ & $\mathrm{P}<0.001$ \\
\hline
\end{tabular}




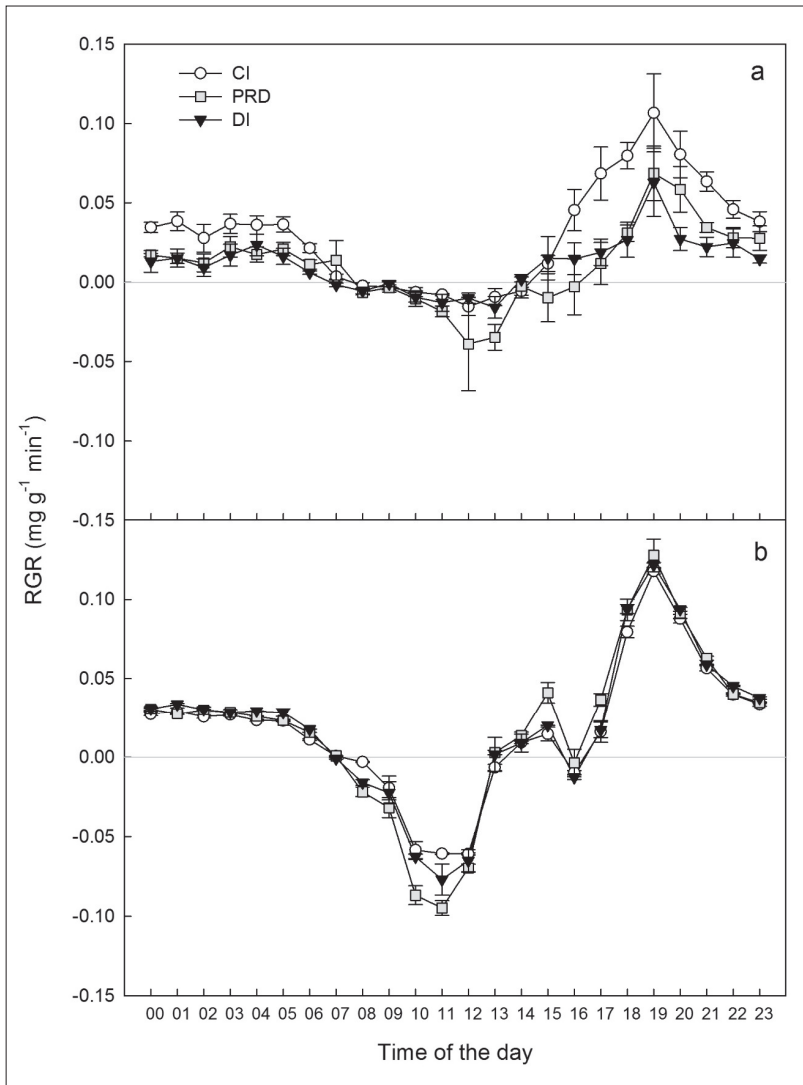

FIGURE 4. Daily trends of young fruit relative growth rate (RGR) in 'Valencia' orange trees under control irrigation (CI), partial root-zone drying (PRD) and continuous deficit irrigation (DI) before (A) and after (B) the harvest of mature fruit. Data are means of five different fruits and seven consecutive days; error bars indicate standard errors of means.

Overall, an increase of fruit AGR was observed from May to June, while RGR remained stable (Table 2). The AGR increase is due to the larger fruitlets rather than to the removal of older sinks, showing that fruitlets are to some extent sink-limited at this stage and keep a constant speed of growth per unit of size. Differences in fruit RGR daily dynamics among irrigation treatments were detected before (May), but not after (June) harvesting the previous-year crop (Figure 4). In May, RGR of PRD and especially DI fruits did not show pronounced daily fluctuations, whereas RGR of CI fruits followed a more marked wave-like trend with positive RGR during early morning, peaks in the evening, and negative RGR in the middle of the day (Figure 4a). In June, fruits started to show more marked RGR fluctuations between night and day than in May, although no significant differences occurred among irrigation treatments (Figure 4b). Those fluctuations showed pronounced negative peaks in the middle of the day and positive peaks in the evening. The results are consistent with the theory that internal competition among plant organs affects fruit growth (Cary, 1970). In May, when the mass of nearly mature fruit was still on the tree, DI and PRD trees were possibly experiencing some shortage of nutrients and carbohydrate reserves as a result of recurrent deficit irrigation. This might justify the higher RGR experienced by CI fruits in the early morning and evening. Water deficit or deficit irrigation may indeed reduce vegetative growth and nutrient absorption, diminishing the overall nutrient and carbon resources of fruit trees (Castel and Buj,
1990; Dry and Loveys, 1998; Peng and Rabe, 1998; Romero et al., 2006; Talluto et al., 2007). High crop load is also known to decrease potassium levels in leaves and shoots of citrus trees (Lenz, 2000). Indeed, internal competition among plant organs may intensify a possible shortage of resources. Mehouachi et al. (1995) attributed fruit growth decreases to low carbohydrate availability, which may also be the case for PRD and DI trees in this experiment. In June, competition between mature fruits and fruitlets was relieved and a greater share of nutrients and assimilates were allocated to young sinks, canceling growth differences among CI, DI and PRD fruits.

\section{Factors influencing daily fruit growth dynamics}

The opposite daily trends exhibited by RGR and VPD (Figures 2 and 4) suggest that the latter may be considered one of the possible environmental factors driving RGR daily dynamics via the transpiration flow and negative water balance. Indeed, sap flow is strongly affected by VPD variations; a direct linear relationship among the two variables was found in $\mathrm{CI}$, PRD and DI trees both in May and June (Figure 5). When sap flow density was related to VPD, the ANOVA test on slopes of those linear relationships revealed that slopes of CI and PRD were similar, whereas sap flow of DI trees had a steeper response to VPD compared to the other irrigation treatments $(\mathrm{P}<0.001)$. Those differences of slopes in favor of DI were observed both in May and June (Figures $5 a$ and b), and were in part canceled when sap flow density was converted into sap flow per tree at least in May (Figure 5c). This suggests that DI trees, which had about $21 \%$ smaller trunks than CI trees (growth reductions due to recurrent deficit irrigation), were able to take up similar amounts of water by increasing the ability to absorb (i.e., deeper root development) and/or conduct water (i.e., increased hydraulic conductivity). This may be a further evidence of an adaptive response of DI trees to recurring water deficit (seven years of summer deficit irrigation) and reduced growth (trunk size).

Sap flow was another important factor driving fruit growth dynamics. In this case, a piece-wise model (two segments) was found which best describes the relationship between sap flow and fruit RGR (Figure 6). A direct linear relationship was found between sap flow and RGR at low sap flow rates (night/early morning), while an inverse relationship was observed when sap flows reached the highest levels (day/evening). This was true both in May (Figure 6a) and June (Figure 6b), although with slightly different (non-significant) breakpoints (i.e., points at which the relationship is inverted). Regardless of fruit harvest or irrigation strategy, the breakpoint always occurred when sap flow was between 27 and $64 \mathrm{~mL} \mathrm{~min}^{-1}$ tree $^{-1}$ (Table 3). This inversion in the relationship between sap flow and fruit RGR might be related to a change in the leaf conductance and consequent capacity to attract water during the day, as well as a competition for water between leaves and fruit. Indeed, most of the xylem water flows to transpiring leaves in the morning and during the mid-part of the day, while fruit xylem inflow and RGR are relatively low as shown in apple (Lang, 1990), peach (Morandi et al., 2007a), kiwifruit (Morandi et al., 2010b), and pear (Morandi et al., 2014). At this time, leaves are strong sinks for water (mainly driven by VPD) and fruit may even lose water (backflow). This explains the negative relationship between sap flow and fruit RGR that was found at high sap flow rates. In the evening, leaf gas exchange typically decreases (Giuliani et al., 1997; Matos et al., 1998; Morandi et al., 2014), and so does stem sap flow, which follows VPD (Figures 4 and 5). 


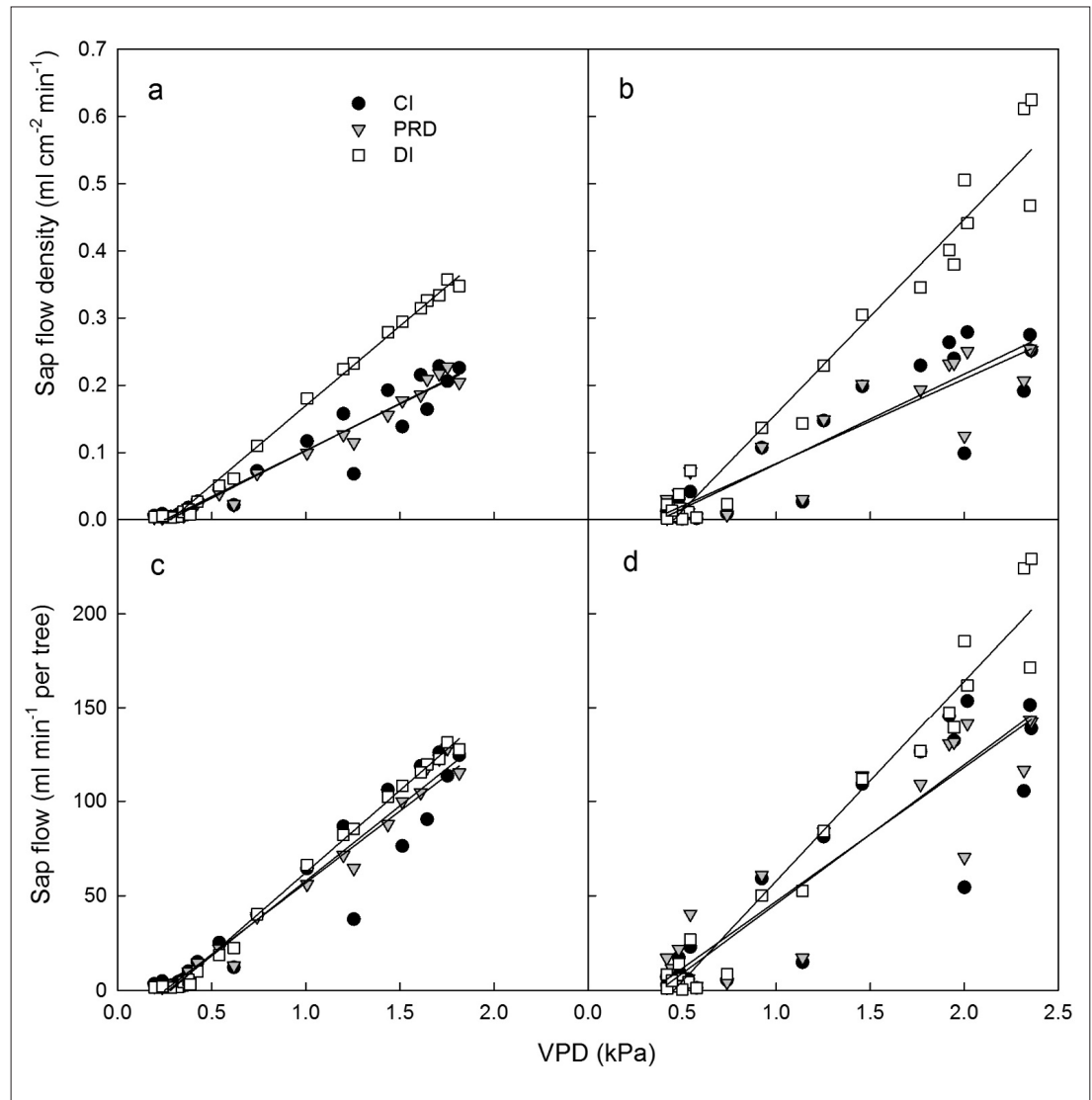

FIGURE 5. Linear relationships between vapor pressure deficit (VPD) and sap flow density (SFD, A and B) or sap flow per tree (SFT, C and D) in 'Valencia' orange trees under control irrigation (CI), partial root-zone drying (PRD) and continuous deficit irrigation (DI) before (A and C) and after (B and D) harvest of mature fruit. In $\mathrm{A}$ : for $\mathrm{CI}, \mathrm{SFD}=$ $0.138 V P D-0.034\left(R^{2}=0.930 ; P<0.001\right)$; for PRD, SFD $=0.141 \mathrm{VPD}-0.038$ $\left(\mathrm{R}^{2}=0.983 ; \mathrm{P}<0.001\right)$; for $\mathrm{DI}, \mathrm{SFD}=$ $0.237 \mathrm{VPD}-0.067\left(\mathrm{R}^{2}=0.994 ; \mathrm{P}<0.001\right)$. In $\mathrm{B}$ : for $\mathrm{CI}, \mathrm{SFD}=0.134 \mathrm{VPD}-0.051$ $\left(\mathrm{R}^{2}=0.841 ; \mathrm{P}<0.001\right)$; for $\mathrm{PRD}, \mathrm{SFD}=$ $0.126 \mathrm{VPD} \quad-0.043 \quad\left(\mathrm{R}^{2}=0.869\right.$; $\mathrm{P}<0.001)$; for DI, SFD $=0.290 \mathrm{VPD}-$ $0.132\left(\mathrm{R}^{2}=0.965 ; \mathrm{P}<0.001\right)$. In $\mathrm{C}$ : for $\mathrm{CI}$, $\mathrm{SFT}=75.8 \mathrm{VPD}-18.9 \quad\left(\mathrm{R}^{2}=0.930\right.$; $\mathrm{P}<0.001)$; for $\mathrm{PRD}, \mathrm{SFT}=79.2 \mathrm{VPD}-$ $21.4\left(\mathrm{R}^{2}=0.983\right.$; $\left.\mathrm{P}<0.001\right)$; for $\mathrm{DI}, \mathrm{SFT}=$ 86.7VPD - 24.4 $\left(\mathrm{R}^{2}=0.994 ; \mathrm{P}<0.001\right)$. In D: for CI, SFT $=73.6 \mathrm{VPD}-28.0$ $\left(\mathrm{R}^{2}=0.841 ; \mathrm{P}<0.001\right)$; for $\mathrm{PRD}, \mathrm{SFT}=$ 71.0VPD - $24.0\left(\mathrm{R}^{2}=0.869 ; \mathrm{P}<0.001\right)$; for $\mathrm{DI}, \quad \mathrm{SFT}=106.2 \mathrm{VPD}-48.4$ $\left(\mathrm{R}^{2}=0.965 ; \mathrm{P}<0.001\right)$.

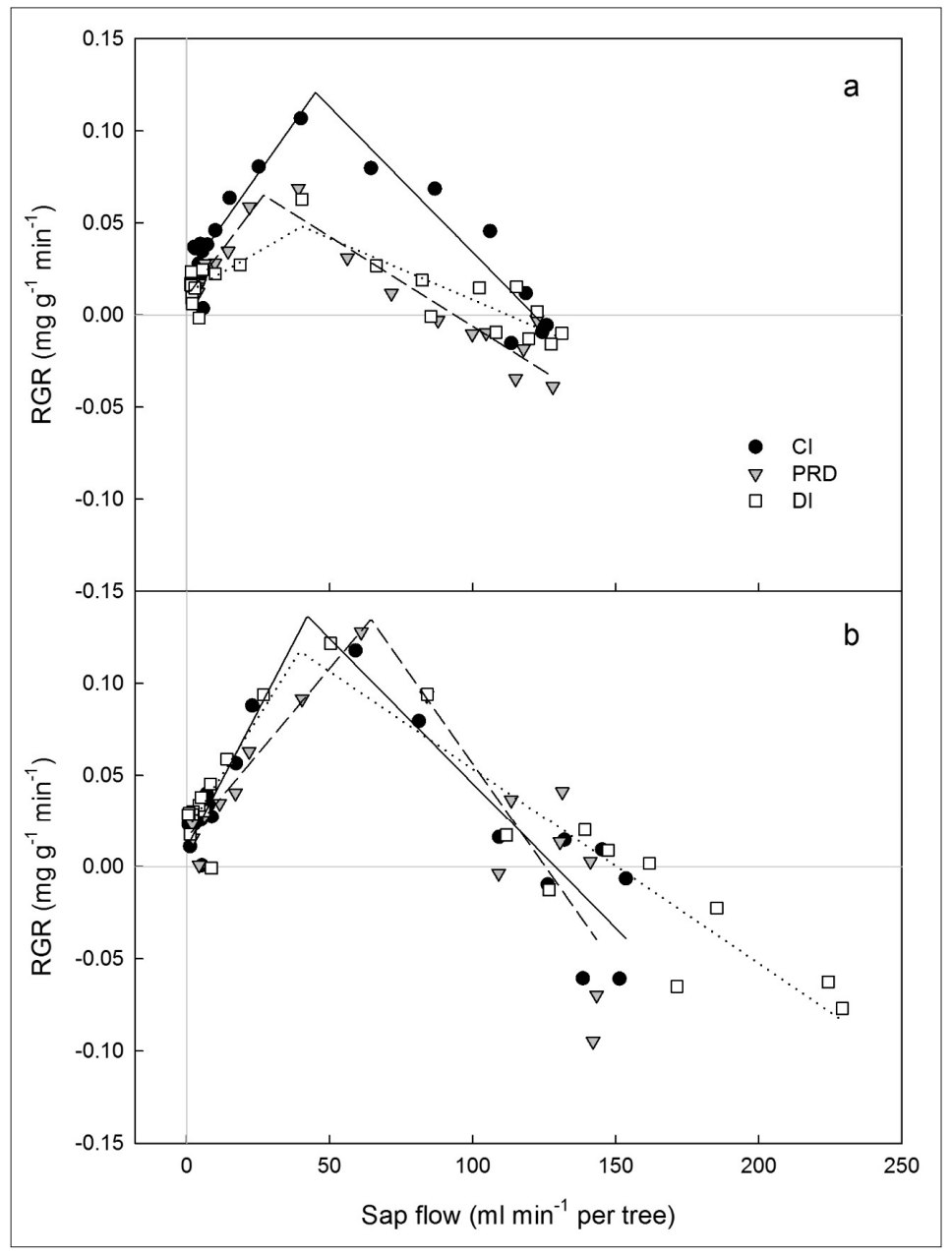

FIGURE 6. Relationships between sap flow and young fruit relative growth rate (RGR) in 'Valencia' orange trees under control irrigation (CI), partial root-zone drying (PRD) and continuous deficit irrigation (DI) before (A) and after (B) the harvest of mature fruit. Data analyzed by piece-wise regression $(\mathrm{P}<0.05)$. 
TABLE 3. Sap flow thresholds and correspondent relative growth rate (RGR) levels in 'Valencia' orange trees under conventional irrigation (CI), partial root-zone drying (PRD) and continuous deficit irrigation (DI) before (May) and after (June) harvest of mature fruit. The sap flow threshold represents the level after which there is an inversion of RGR trend (breakpoint) in the piece-wise relationship, shifting from increasing to decreasing RGR. Coefficients \pm standard errors.

\begin{tabular}{lccc}
\hline Month & Irrigation & $\begin{array}{c}\text { Sap flow threshold } \\
\left(\mathrm{mL} \mathrm{min}^{-1} \text { tree }\right)\end{array}$ & $\begin{array}{c}\text { RGR } \\
\left(\mathrm{mg} \mathrm{g}^{-1} \mathrm{~min}^{-1}\right)\end{array}$ \\
\hline May & $\mathrm{Cl}$ & $45.0 \pm 5.48$ & $0.12 \pm 0.011 \mathrm{a}^{2}$ \\
& $\mathrm{PRD}$ & $26.9 \pm 4.09$ & $0.07 \pm 0.006 \mathrm{~b}$ \\
& $\mathrm{DI}$ & $40.3 \pm 8.96$ & $0.05 \pm 0.007 \mathrm{~b}$ \\
\hline June & $\mathrm{Cl}$ & $42.2 \pm 8.29$ & $0.14 \pm 0.02$ \\
& $\mathrm{PRD}$ & $64.4 \pm 9.27$ & $0.14 \pm 0.02$ \\
& $\mathrm{DI}$ & $39.5 \pm 8.56$ & $0.12 \pm 0.01$ \\
\hline
\end{tabular}

${ }^{2}$ Different letters indicate significant differences among irrigation treatments and within each month.

Usually, this is the time when fruit start rehydrating via xylem flow (Morandi et al., 2010b, 2014), thus showing increases in RGR and in our case, a positive relationship with sap flow.

No significant differences were found among the breakpoints of CI, PRD and DI, and between May and June. This means that the sap flow level at which the trend inversion in the relationship with RGR occurs does not depend on the number of fruit sinks present on the tree (i.e., competition) or the VPD differences between May and June. The moment at which trend inversion occurs is rather strictly related to rigid thresholds set by a plant response to the environment (i.e., VPD). Indeed, VPD thresholds for fruit RGR inversions can be found using the linear relationships between VPD and sap flow (Figure 5), and range from 0.61 to $1.24 \mathrm{kPa}$.

In May, when the inversion of trend occurred, CI fruit had reached higher RGR levels compared to PRD and DI, although sap flow was not different among treatments (Table 3). The same behavior was not observed in June, probably because competition from mature fruit was relieved and PRD and DI fruitlets resumed growth to CI levels. This is a further indication of source limitation in PRD and DI due to recurrent deficit irrigation.

\section{Conclusions}

Changes in environmental conditions (VPD), fruitlet development stage (cell division to cell enlargement) and vegetative growth affect tree water status more than the presence/removal of a full load of mature fruit in 'Valencia' oranges. On the other hand, the presence of mature fruits may aggravate competition for nutrients and/or carbon reserves in deficit irrigated trees suggesting greater source limitation to young fruit growth than in regularly irrigated trees. This temporary gap in fruit growth is cancelled during the long period of fruit development typical of 'Valencia' oranges, indicating that the concurrent presence of young and mature fruits causes no major detriment to final yields.

Based on fruit growth-environment interactions, orange trees under PRD did not show major modifications or adaptation mechanisms to soil moisture deficit, a further evidence of the lack of dehydration symptoms/effects under the specific conditions of this irrigation strategy. On the contrary, several cycles of water deficit applied to the entire root-zone (DI) seem to induce some morphological and physiological changes, which allow for water flows similar to non-stressed trees (CI) during periods of water deficit relief.

\section{Acknowledgments}

We would like to express our sincere thanks to Prof. Luca Corelli Grappadelli for his useful advice and support with the use of fruit gauges.

\section{References}

Almeida-Rodriguez, A.M., Hacke, U.G., and Laur, J. (2011). Influence of evaporative demand on aquaporin expression and root hydraulics of hybrid poplar. Plant Cell Environ. 34, 1318-1331. https://doi. org/10.1111/j.1365-3040.2011.02331.x.

Bain, J. (1958). Morphological, anatomical, and physiological changes in the developing fruit of the Valencia orange, Citrus sinensis (L.) Osbeck. Aust. J. Bot. 6, 1-23. https://doi.org/10.1071/BT9580001.

Brunner, I., Herzog, C., Dawes, M.A., Arend, M., and Sperisen, C. (2015). How tree roots respond to drought. Front. Plant Sci. 6, 547. https://doi.org/10.3389/fpls.2015.00547.

Cary, P. (1970). Growth, yield and fruit composition of 'Washington Navel' orange cuttings, as affected by root temperature, nutrient supply and crop load. Hortic. Res. 10, 20-23. https://doi. org/10.1071/EA9770336.

Castel, J., and Buj, A. (1990). Response of Salustiana oranges to high frequency deficit irrigation. Irrig. Sci. 11, 121-127. https://doi. org/10.1007/BF00188448.

Chaves, M., Santos, T., Souza, C., Ortuño, M., Rodrigues, M., Lopes, C., Maroco, J., and Pereira, J. (2007). Deficit irrigation in grapevine improves water-use efficiency while controlling vigour and production quality. Ann. Appl. Biol. 150, 237-252. https://doi. org/10.1111/j.1744-7348.2006.00123.x.

Cifre, J., Bota, J., Escalona, J., Medrano, H., and Flexas, J. (2005). Physiological tools for irrigation scheduling in grapevine (Vitis vinifera L.). Agric. Ecosyst. Environ. 106, 159-170. https://doi. org/10.1016/j.agee.2004.10.005.

Coelho, R.D., Vellame, L.M., and Fraga Júnior, E.F. (2012). Estimation of transpiration of the 'Valencia' orange young plant using thermal dissipation probe method. Eng. Agríc. 32, 573-581. https://doi. org/10.1590/S0100-69162012000300016.

Conejero, W., Ortuño, M.F., Mellisho, C.D., and Torrecillas, A. (2010). Influence of crop load on maximum daily trunk shrinkage reference equations for irrigation scheduling of early maturing peach trees. Agr. Water Manage. 97, 333-338. https://doi.org/10.1016/j. agwat.2009.10.003.

Consoli, S., Stagno, F., Vanella, D., Boaga, J., Cassiani, G., and Roccuzzo, G. (2017). Partial root-zone drying irrigation in orange orchards: Effects on water use and crop production characteristics. Eur. J. Agron. 82, 190-202. https://doi.org/10.1016/j.eja.2016.11.001.

Davies, W.J., Wilkinson, S., and Loveys, B. (2002). Stomatal control by chemical signalling and the exploitation of this mechanism to increase water use efficiency in agriculture. New Phytol. 153, 449460. https://doi.org/10.1046/j.0028-646X.2001.00345.x.

De Souza, M.C., and Habermann, G. (2012). Towards a new ecophysiological approach to understand Citrus crop yield under abiotic stresses mirroring in the Brazilian savanna genetic resources. In Water Stress, I.M. Rahman, and H. Hasegawa, eds. (Rijeka, Croatia: InTech), p. 151-164.

Dos Santos, T.P., Lopes, C.M., Rodrigues, M.L., De Souza, C.R., Maroco, J.P., Pereira, J.S., Silva, J.R., and Chaves, M.M. (2003). Partial rootzone drying: effects on growth and fruit quality of field-grown grapevines (Vitis vinifera). Funct. Plant Biol. 30, 663-671. https:// doi.org/10.1071/FP02180. 
Dry, P., and Loveys, B. (1998). Factors influencinggrapevine vigour and the potential for control with partial rootzone drying. Aust. J. Grape Wine Res. 4, 140-148. https://doi.org/10.1111/j.1755-0238.1998. tb00143.x.

English, M. (1990). Deficit irrigation. I: Analytical framework. J. Irrig. Drain. E-Asce 116, 399-412. https://doi.org/10.1061/(ASCE)07339437(1990)116:3(399).

Faber, B.A., and Lovatt, C.J. (2014). Effects of applying less water by partial root zone drying versus conventional irrigation on navel orange yield. Acta Hortic. 1038, 523-530. https://doi.org/10.17660/ ActaHortic.2014.1038.65.

Fonti, P., and Jansen, S. (2012). Xylem plasticity in response to climate. New Phytol. 195, 734-736. https://doi.org/10.1111/j.14698137.2012.04252.x

Francaviglia, D., Farina, V., Avellone, G., and Lo Bianco, R. (2013). Fruit yield and quality responses of apple cvs. Gala and Fuji to partial rootzone drying under Mediterranean conditions. J. Agric. Sci. 151, 556-569. https://doi.org/10.1017/S0021859612000718.

Garcia-Luis, A., Oliveira, M.E.M., Bordón, Y., Siqueira, D.L., Tominaga, S., and Guardiola, J.L. (2002). Dry matter accumulation in citrus fruit is not limited by transport capacity of the pedicel. Ann. Bot. 90, 755764. https://doi.org/10.1093/aob/mcf257.

García-Tejero, I., Durán-Zuazo, V.H., Jiménez-Bocanegra, J.A., and Muriel-Fernández, J.L. (2011). Improved water-use efficiency by deficit-irrigation programmes: implications for saving water in citrus orchards. Sci. Hortic. 128, 274-282. https://doi.org/10.1016/j. scienta.2011.01.035.

García-Tejero, I.F., Durán-Zuazo, V.H., Arriaga, J., and MurielFernández, J.L. (2012). Relationships between trunk- and fruitdiameter growths under deficit-irrigation programmes in orange trees. Sci. Hortic. 133, 64-71. https://doi.org/10.1016/j. scienta.2011.10.022.

Giuliani, R., Nerozzi, F., Magnanini, E., and Corelli-Grappadelli, L. (1997). Influence of environmental and plant factors on canopy photosynthesis and transpiration of apple trees. Tree Physiol. 17, 637-645. https://doi.org/10.1093/treephys/17.10.637.

Goldhamer, D.A., and Salinas, M. (2000). Evaluation of regulated deficit irrigation on mature orange trees grown under high evaporative demand. Paper presented at: IX Congress of the International Society of Citriculture (Orlando, USA).

Gowing, D.J.G., Davies, W.J., and Jones, H.G. (1990). A positive root-sourced signal as an indicator of soil drying in apple, Malus $\times$ domestica Borkh. J. Exp. Bot. 41, 1535-1540. https://doi. org/10.1093/jxb/41.12.1535.

Granier, A. (1985). Une nouvelle méthode pour la mésure du flux de sève brute dans le tronc des arbres. Ann. Sci. For. 42, 193-200. https://doi.org/10.1051/forest:19850204

Guardiola, J. (1988). Factors limiting productivity in citrus. A physiological approach. Paper presented at: VI Congress of the International Society of Citriculture (Tel-Aviv, Israel).

Hartmann, H. (2011). Will a 385 million year-struggle for light become a struggle for water and for carbon? How trees may cope with more frequent climate change-type drought events. Global Change Biol. 17, 642-655. https://doi.org/10.1111/j.13652486.2010.02248.x

Huang, T., Darnell, R., and Koch, K. (1992). Water and carbon budgets of developing citrus fruit. J. Amer Soc. Hort. Sci. 117, 287-293.

Iglesias, D.J., Cercós, M., Colmenero-Flores, J.M., Naranjo, M.A., Ríos, G., Carrera, E., Ruiz-Rivero, O., Lliso, I., Morillon, R., Tadeo, F.R., and Talon, M. (2007). Physiology of citrus fruiting. Braz.J. Plant Physiol. 19, 333-362. https://doi.org/10.1590/s1677-04202007000400006.
Intrigliolo, D., and Castel, J. (2006). Performance of various water stress indicators for prediction of fruit size response to deficit irrigation in plum. Agric. Water Manage. 83, 173-180. https://doi. org/10.1016/j.agwat.2005.12.005.

Kang, S., and Zhang, J. (2004). Controlled alternate partial root-zone irrigation: its physiological consequences and impact on water use efficiency. J. Exp. Bot. 55, 2437-2446. https://doi.org/10.1093/jxb/ erh249.

Kozlowski, T., and Pallardy, S. (2002). Acclimation and adaptive responses of woody plants to environmental stresses. Bot. Rev. 68, 270-334. https://doi.org/10.1663/0006-8101(2002)068[0270:AA AROW]2.0.C0;2.

Kusakabe, A., Contreras-Barragan, B.A., Simpson, C.R., Enciso, J.M., Nelson, S.D., and Melgar, J.C. (2016). Application of partial rootzone drying to improve irrigation water use efficiency in grapefruit trees. Agr. Water Manage. 178, 66-75. https://doi.org/10.1016/j. agwat.2016.09.012.

Lang, A. (1990). Xylem, phloem and transpiration flows in developing apple fruits. J. Exp. Bot. 41, 645-651. https://doi.org/10.1093/ $\mathrm{jxb} / 41.6 .645$.

Lenz, F. (2000). Effects of fruit load on the nutrient uptake and distribution in citrus trees. Acta Hortic. 531, 115-120. https://doi. org/10.17660/ActaHortic.2000.531.16.

Link, S.O., Thiede, M.E., and Van Bavel, M.G. (1998). An improved strain-gauge device for continuous field measurement of stem and fruit diameter. J. Exp. Bot. 49, 1583-1587. https://doi.org/10.1093/ jexbot/49.326.1583.

Lo Bianco, R. (2013). Responses of apple to partial root-zone drying: A review. In Irrigation Management, Technologies and Environmental Impact, H.I. Ali, ed. (New York, USA: Nova Science Publishers), p. 71-86.

Lo Bianco, R., and Francaviglia, D. (2012). Comparative responses of 'Gala' and 'Fuji' apple trees to deficit irrigation: Placement versus volume effects. Plant Soil 357, 41-58. https://doi.org/10.1007/ s11104-012-1149-z.

Matos, M., Matos, A., Mantas, A., Cordeiro, V., and Vieira Da Silva, J. (1998). Diurnal and seasonal changes in Prunus amygdalus gas exchanges. Photosynthetica 35, 517-524. https://doi. org/10.1023/A:1006922822385.

McCutchan, H., and Shackel, K. (1992). Stem-water potential as a sensitive indicator of water stress in prune trees (Prunus domestica L. cv. French). J. Amer. Soc. Hort. Sci. 117, 607-611.

Mehouachi, J., Serna, D., Zaragoza, S., Agusti, M., Talon, M., and PrimoMillo, E. (1995). Defoliation increases fruit abscission and reduces carbohydrate levels in developing fruits and woody tissues of Citrus unshiu. Plant Sci. 107, 189-197. https://doi.org/10.1016/01689452(95)04111-7.

Morandi, B., Rieger, M., and Corelli Grappadelli, L. (2007a). Vascular flows and transpiration affect peach (Prunus persica Batsch.) fruit daily growth. J. Exp. Bot. 58, 3941-3947. https://doi.org/10.1093/ jxb/erm248.

Morandi, B., Manfrini, L., Zibordi, M., Noferini, M., Fiori, G., and Corelli Grappadelli, L. (2007b). A low-cost device for accurate and continuous measurements of fruit diameter. HortScience 42, 13801382.

Morandi, B., Manfrini, L., Losciale, P., Zibordi, M., and Corelli Grappadelli, L. (2010a). The positive effect of skin transpiration in peach fruit growth. J. Plant Physiol. 167, 1033-1037. https://doi. org/10.1016/j.jplph.2010.02.015.

Morandi, B, Manfrini, L., Losciale, P., Zibordi, M., and Corelli Grappadelli, L. (2010b). Changes in vascular and transpiration 
flows affect the seasonal and daily growth of kiwifruit (Actinidia deliciosa) berry. Ann. Bot. 105, 913-923. https://doi.org/10.1093/ aob/mcq070.

Morandi, B., Zibordi, M., Losciale, P., Manfrini, L., Pierpaoli, E., and Corelli Grappadelli, L. (2011). Shading decreases the growth rate of young apple fruit by reducing their phloem import. Sci. Hortic. 127, 347-352. https://doi.org/10.1016/j.scienta.2010.11.002.

Morandi, B., Losciale, P., Manfrini, L., Pierpaoli, E., Zibordi, M., and Corelli Grappadelli, L. (2012). Short-period changes in weather conditions affect xylem, but not phloem flows to young kiwifruit (Actinidia deliciosa) berries. Sci. Hortic. 142, 74-83. https://doi. org/10.1016/j.scienta.2012.04.029.

Morandi, B., Losciale, P., Manfrini, L., Zibordi, M., Anconelli, S., Pierpaoli, E., and Corelli Grappadelli, L. (2014). Leafgas exchanges and water relations affect the daily patterns of fruit growth and vascular flows in Abbé Fétel pear (Pyrus communis L.) trees. Sci. Hortic. 178, 106-113. https://doi.org/10.1016/j.scienta.2014.08.009.

Morison, J.I., Baker, N., Mullineaux, P., and Davies, W. (2008). Improving water use in crop production. Phil. Trans. R. Soc. B. Biol. Sci. 363, 639-658. https://doi.org/10.1098/rstb.2007.2175.

Mossad, A., Scalisi, A., and Lo Bianco, R. (2017). Growth and water relations of field-grown 'Valencia' orange trees under longterm partial rootzone drying. Irrig. Sci. 36(1), 9-24. https://doi. org/10.1007/s00271-017-0562-8.

Naor, A. (2006). Irrigation scheduling and evaluation of tree water status in deciduous orchards. In Horticultural Reviews, Vol. 32, J. Janick, ed. (Oxford, UK: John Wiley \& Sons, Inc.), p. 111-165. https://doi.org/10.1002/9780470767986.ch3.

Naor, A., Klein, I., and Doron, I. (1995). Stem water potential and apple size. J. Amer. Soc. Hort. Sci. 120, 577-582.

Naor, A., Hupert, H., Greenblat, Y., Peres, M., Kauffman, A., and Klein, I. (2001). The response of nectarine fruit size and midday stem water potential to irrigation level in stage III and crop load. J. Amer. Soc. Hort. Sci. 126, 140-143.

Naor, A., Naschitz, S., Peres, M., and Gal, Y. (2008). Responses of apple fruit size to tree water status and crop load. Tree Physiol. 28, 12551261. https://doi.org/10.1093/treephys/28.8.1255.

Navarro, J.M., Pérez-Pérez, J.G., Romero, P., and Botía, P. (2010). Analysis of the changes in quality in mandarin fruit, produced by deficit irrigation treatments. Food Chem. 119, 1591-1596. https:// doi.org/10.1016/j.foodchem.2009.09.048

Parent, B., Hachez, C., Redondo, E., Simonneau, T., Chaumont, F., and Tardieu, F. (2009). Drought and abscisic acid effects on aquaporin content translate into changes in hydraulic conductivity and leaf growth rate: a trans-scale approach. Plant Physiol. 149, 2000-2012. https://doi.org/10.1104/pp.108.130682.

Pavel, E., and DeJong, T. (1993). Source- and sink-limited growth periods of developing peach fruits indicated by relative growth rate analysis. J. Amer. Soc. Hort. Sci. 118, 820-824.

Peng, Y., and Rabe, E. (1998). Effect of differing irrigation regimes on fruit quality, yield, fruit size and net $\mathrm{CO}_{2}$ assimilation of 'Mihowase' satsuma. J. Hortic. Sci. Biotechnol. 73, 229-234. https://doi.org/10.1 080/14620316.1998.11510969.

Perez-Perez, J.G., Dodd, I.C., and Botia, P. (2012). Partial rootzone drying increases water-use efficiency of lemon Fino 49 trees independently of root-to-shoot ABA signalling. Funct. Plant Biol. 39, 366-378. https://doi.org/10.1071/FP11269.
Prado, A.K.S., Machado, E.C., Medina, C.L., Fávero, D., and Mazzafera, P. (2007). Florescimento e frutificação em laranjeiras 'Valencia' com diferentes cargas de frutos e submetidas ou não à irrigação. Bragantia 66, 173-182. https://doi.org/10.1590/s000687052007000200001 .

Rokach, A. (1953). Water transfer from fruits to leaves in the Shamouti orange tree and related topics. Palestine J. Bot. 8, 146-151.

Romero, P., Navarro, J.M., Perez-Perez, J., García-Sánchez, F., GómezGómez, A., Porras, I., Martinez, V., and Botía, P. (2006). Deficit irrigation and rootstock: their effects on water relations, vegetative development, yield, fruit quality and mineral nutrition of Clemenules mandarin. Tree Physiol. 26, 1537-1548. https://doi.org/10.1093/ treephys/26.12.1537.

Schroeder, C., and Wieland, P. (1956). Diurnal fluctuation in size in various parts of the avocado tree and fruit. Proc. Amer. Soc. Hort. Sci. $68,253-258$.

Silber, A., Israeli, Y., Levi, M., Keinan, A., Chudi, G., Golan, A., Noy, M., Levkovitch, I., Narkis, K., Naor, A., and Assouline, S. (2013). The roles of fruit sink in the regulation of gas exchange and water uptake: A case study for avocado. Agr. Water Manage. 116, 21-28. https:// doi.org/10.1016/j.agwat.2012.10.006.

Talluto, G., Farina, V., and Lo Bianco, R. (2007). Growth, fruit yield and quality of 'Golden Delicious' apple trees under fixed partial rootzone drying. J. Appl. Hortic. 9, 50-55.

Talluto, G., Farina, V., Volpe, G., and Lo Bianco, R. (2008). Effects of partial rootzone drying and rootstock vigour on growth and fruit quality of 'Pink Lady' apple trees in Mediterranean environments. Aust. J. Agric. Res. 59, 785-794. https://doi.org/10.1071/ar07458.

Teskey, R.O., and Hinckley, T.M. (1981). Influence of temperature and water potential on root growth of white oak. Physiol. Plant. 52, 363369. https://doi.org/10.1111/j.1399-3054.1981.tb06055.x.

Treeby, M.T., Henriod, R.E., Bevington, K.B., Milne, D.J., and Storey, R. (2007). Irrigation management and rootstock effects on navel orange [Citrus sinensis (L.) Osbeck] fruit quality. Agr. Water Manage. 91, 24-32. https://doi.org/10.1016/j.agwat.2007.04.002.

Valiente, J.I., and Albrigo, L.G. (2004). Flower bud induction of sweet orange trees [Citrus sinensis (L.) Osbeck]: effect of low temperatures, crop load, and bud age. J. Amer. Soc. Hort. Sci. 129, 158-164.

Zeng, Q., Liu, C., Miao, Y., Fei, S., and Wang, S. (2008). A machine vision system for continuous field measurement of grape fruit diameter Paper presented at: $2^{\text {nd }}$ International Symposium on Intelligent Information Technology Application (Shanghai, China).

Received: Nov. 14, 2017

Accepted: Nov. 2, 2018

Addresses of authors:

Filipa S. Grilo ${ }^{1}$, Alessio Scalisi ${ }^{1}$, Fulvio Pernice ${ }^{1}$, Brunella Morandi ${ }^{2}$ and Riccardo Lo Bianco ${ }^{1, *}$

${ }^{1}$ Department of Agricultural, Food and Forest Sciences, University of Palermo, Viale delle Scienze 11, 90128 Palermo, Italy

2 Department of Agricultural Sciences, University of Bologna, Viale Fanin 44, 40127 Bologna, Italy

* Corresponding author;

E-mail: riccardo.lobianco@unipa.it;

Tel.: +39-091-23896097 